Review

\title{
Laser Use in Creating Orthodontic Adhesion to Ceramic Surfaces
}

\author{
Anca Labunet ${ }^{1} \mathbb{D}$, Andreea Kui ${ }^{2, *} \mathbb{D}$ and Sorina Sava ${ }^{1}$ \\ 1 Department of Dental Materials and Ergonomics, Iuliu Hatieganu Medicine and Pharmacy University \\ Cluj-Napoca, Avram Iancu 31 Street, 400083 Cluj-Napoca, Romania; labunet@yahoo.com (A.L.); \\ savasorina@yahoo.com (S.S.) \\ 2 Department of Prosthodontics Iuliu Hatieganu Medicine and Pharmacy University, Clinicilor 32 Street, \\ 400006 Cluj-Napoca, Romania \\ * Correspondence: andreeakui@gmail.com; Tel.: +40-264597844
}

\section{check for}

updates

Citation: Labunet, A.; Kui, A.; Sava, S. Laser Use in Creating Orthodontic Adhesion to Ceramic Surfaces. Appl. Sci. 2021, 11, 2512. https://doi.org/ 10.3390/app11062512

Academic Editor: Mary Anne Melo

Received: 12 February 2021

Accepted: 8 March 2021

Published: 11 March 2021

Publisher's Note: MDPI stays neutral with regard to jurisdictional claims in published maps and institutional affiliations.

Copyright: (c) 2021 by the authors. Licensee MDPI, Basel, Switzerland. This article is an open access article distributed under the terms and conditions of the Creative Commons Attribution (CC BY) license (https:// creativecommons.org/licenses/by/ $4.0 /)$.

\begin{abstract}
Orthodontists must sometimes bond attachments to ceramic crowns, by using one of the surface preparations available, such as sandblasting or acid etching with hydrofluoric acid. Research shows that different laser systems may also be used for this purpose. The aim of this review is to determine which laser type and modality of use is the most effective in increasing shear bond strength of brackets bonded to ceramic surfaces. Two independent researchers studied the current literature 1990-2018 and selected original articles focusing on in vitro research on laser use for ceramic surface preparation for bonding metallic or ceramic attachments. Twelve articles have met the criteria and have been thoroughly revised, focusing on 2 fractional, Nd:Yag, Er:Yag, femtosecond and Ti:Sapphire lasers. There is little difference shown by the current studies between ceramic types and information on orthodontic bonding to non-feldspathic ceramics is scarce. Femtosecond laser is a good alternative to classical surface preparation with hydrofluoric acid. Nd:Yag laser is more suitable for surface preparation of ceramics than different types of Er:Yag lasers. Difference in laser power may achieve different results, but the golden standard for lasers use has not been found. Laser usage does not obtain the same results as hydrofluoric acid and cannot, so far, eliminate its application.
\end{abstract}

Keywords: laser; orthodontics; ceramics

\section{Introduction}

Introduction of lasers in dentistry was announced in 1960, by Miaman [1] and its use was continuously extended and researched. There are hard lasers, such as, carbon dioxide $\left(\mathrm{CO}_{2}\right)$, neodymium yttrium aluminium garnet (Nd:YAG), erbium-doped yttrium aluminium garnet laser (Er:YAG) and cold or soft lasers which are known as low-level laser therapy or 'biostimulation' [2]. In order to ensure laser efficacity on a certain surface, an adequate intensity on the surface must be obtained. Also, it should couple as high a fraction of incident power into the material as possible. Laser beam properties, that may influence these characteristics, are: wavelength, responsible for the focusability and absorptivity of the beam; power and achievable spot diameter, which determine the intensity in the interaction zone; beam quality, being a measure of the available focused spot diameter and beam divergence angle product; finally, the polarisation of the beam, which has a considerable influence on the absorptivity for large angles of incidence [3].

Lasers may be used for most of the common dental procedures, such as frenectomies, crown lengthening, composite curing, and control of haemorrhage disorders, caries detection and removal, reduction of pain and treatments of hypersensitivity, gingivectomy, gingivoplasty, soft-tissue lesions and aphthous ulcers [4].

A short presentation of lasers used in dentistry facilitates understanding of this review [5]. The $\mathrm{CO}_{2}$ laser wavelength has a very high affinity for water, resulting in rapid soft tissue removal and haemostasis with a very shallow depth of penetration. Its disadvantages are its large size and high cost and destructive interactions with hard tissue. 
The Nd:YAG wavelength is an effective surgical laser for cutting and coagulating dental soft tissues, with good haemostasis, that has also been used in periodontal treatments.

The erbium lasers have two distinct wavelengths, Er Cr:YSGG (yttrium scandium gallium garnet) lasers and Er:YAG (yttrium aluminium garnet) lasers, with a high affinity for hydroxyapatite and the highest absorption of water in any dental laser wavelengths, thus being used for the treatment of dental hard tissues [6]. Erbium lasers can also be used for soft tissue ablation [7].

The diode laser has an active medium made of aluminium, gallium, arsenide and indium. It is mostly used for aesthetic gingival re-contouring, soft tissue crown lengthening, exposure of soft tissue impacted teeth, removal of inflamed and hypertrophic tissue, frenectomies and photostimulation of the apthous and herpetic lesions [8]. One of the diode laser types that is also used in dentistry is titanium-doped sapphire. It is a widelyused gain medium, with an active ion which has a large bandwidth in a host crystal that is hard and has high thermal conductivity [9].

A femtosecond laser emits optical pulses with a duration in the domain of femtoseconds1 ps. It is included in the category of ultrafast or ultrashort pulse lasers. Femtosecond pulsation may be obtained by various diode-pumped lasers, such as neodymium-doped or ytterbium-doped gain media. Diode lasers and titanium-sapphire lasers are also suitable for pulse durations below $10 \mathrm{fs}$ [3].

Other classifications of lasers are presented in Table 1.

Table 1. Different lasers classifications.

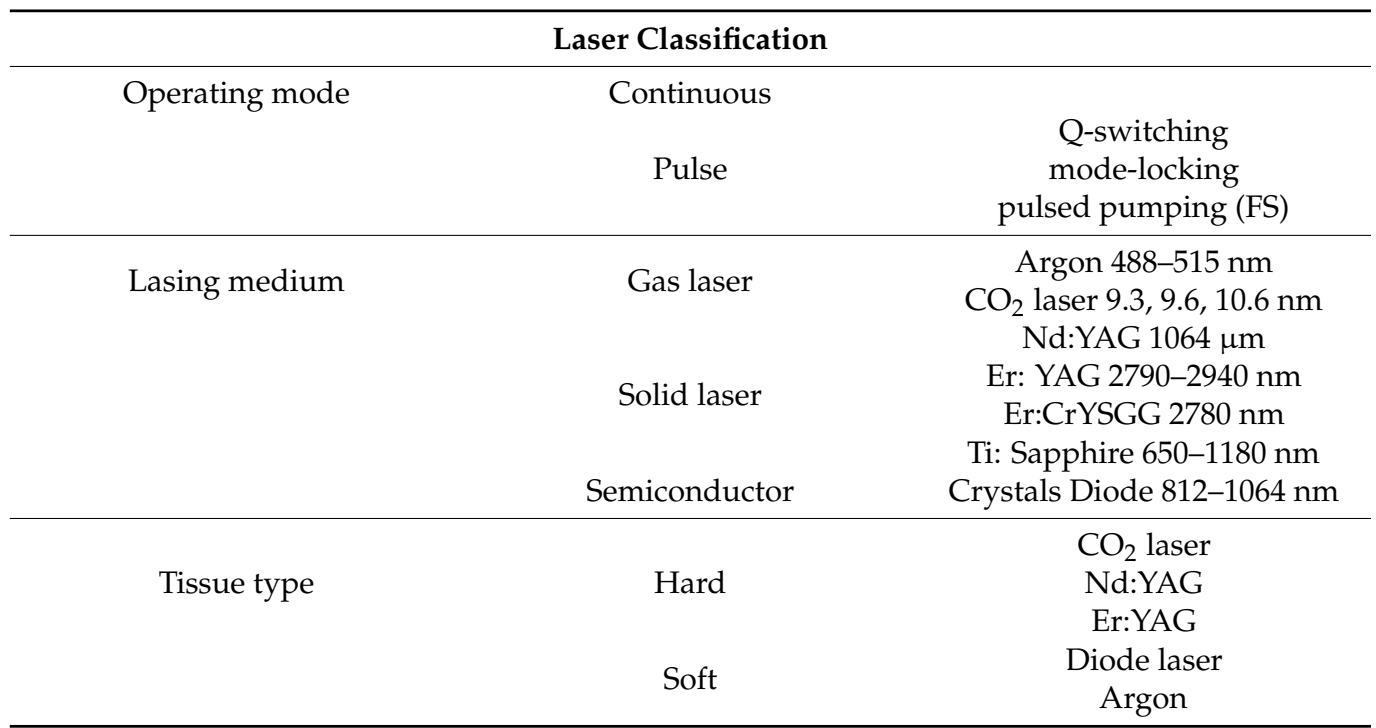

In orthodontic practice, lasers have many common applications, including acceleration of tooth movement, bone remodelling, enamel etching prior to bonding, debonding of ceramic brackets and pain reduction after orthodontic force and prevention of enamel demineralisation or soft tissue modelling [10].

At times, orthodontists must bond attachments to ceramic crowns, as they are commonly used in prosthodontic procedures. This type of bonding may cause some concerns, as there are several types of surface preparations that may be used. Surface roughness is needed for creating microretention for the adhesive layer used to bond brackets. Traditionally, surface roughness was gained by sandblasting or acid etching with hydrofluoric (HF) acid. With the development of laser systems, research focused on this technique for surface etching of ceramics in order to evaluate its efficacity [11].

This review aims to assess research, creating a thorough image of laser use in ceramic restorations for bonding orthodontic attachments. Adhesion of orthodontic attachments may be tested easily and thoroughly, as their small bonding surface of just a few square mil- 
limetres and the possibility to debond without breaking the ceramics gives the opportunity of new research.

\section{Materials and Methods}

Two independent researchers searched Pubmed, Medline, Embase databases in February 2018, focusing on the bonding process of orthodontic attachments to ceramic surfaces by using search terms such as ceramics bond orthodontics, ceramics adhesion orthodontics. Articles published in the time frame 1990-2018 were revised. This search line was then limited to laser use in preparing a bonding surface on the ceramics. Only original articles were selected for this study. Exclusions concerned bonding to non-ceramic surfaces or bonding to ceramic surfaces that are not destined for orthodontics, laser usage for bracket base preparation. Exclusions have been made by reading titles and abstracts. Only experimental, in vitro studies, have been included, as clinical studies are difficult to reproduce and the influence of several factors, different use of appliances, doctor's capabilities, varies. Researchers finally listed articles that focused on bonding brackets of metallic and ceramic types to ceramic surfaces by means of a laser appliance.

\section{Results}

After the search has been performed, a total number of 314 articles have been found. After applying the inclusion and exclusion criteria, twelve articles were included in the process of revision. They are presented in Table 2.

Table 2. Articles of laser usage for bonding to ceramic surfaces.

\begin{tabular}{|c|c|c|c|c|c|c|c|}
\hline No Ref. & Ceramic Type & Samples No & Bracket Type & Laser Type & Adhesion Type & Results & $\begin{array}{c}\text { Additional } \\
\text { Examination }\end{array}$ \\
\hline [12] & Zirconia & 180 & Metallic & $\begin{array}{l}\text { Ti:sapphire } \\
\text { Femtosecond }\end{array}$ & $\begin{array}{c}\text { Control/air particle } \\
\text { abrasion/femtosecond } \\
\text { laser } 300 \mathrm{~mW}, 60 \mu \mathrm{m} / \mathrm{Fs} \\
\text { laser } 200 \mathrm{~mW}, 100 \mathrm{um} / \mathrm{FS} \\
\text { laser } 40 \mathrm{~mW}, 60 \mu \mathrm{m} / \mathrm{FS} \\
\text { laser } 200 \mathrm{~mW}, 60 \mu \mathrm{m}\end{array}$ & $\begin{array}{c}\text { FS laser } 300 \mathrm{~mW}, 60 \mu \mathrm{m} \\
\text { and FS laser } 200 \mathrm{~mW}, \\
60 \mu \mathrm{m} \text { higher SBS, } 200 \mathrm{~mW}, \\
60 \mu \mathrm{m} \text { ideal FS settings }\end{array}$ & \\
\hline [13] & Zirconia & 300 & $\begin{array}{l}\text { Metallic and } \\
\text { ceramic }\end{array}$ & $\begin{array}{l}\text { Ti:sapphire } \\
\text { Femtosecond }\end{array}$ & $\begin{array}{l}\text { Control/APA/silica } \\
\text { coating and silane } \\
\text { (SC)/femtosecond laser } \\
\text { (FS)/APA+FS }\end{array}$ & $\begin{array}{c}\text { SBS sgn higher for ceramic } \\
\text { brackets in all groups } \\
\text { APA+FS }>\text { APA > FS > SC > } \\
\text { control } \\
\text { Metallic brackets, groups } \\
\text { SC, FS, APA+FS sgn higher } \\
\text { SBS than other groups. FS } \\
\text { increases SBS to metallic } \\
\text { and ceramic }\end{array}$ & $\begin{array}{c}\text { Thermal imaging } \\
\text { camera for } \\
\text { temperature } \\
\text { changes }\end{array}$ \\
\hline [14] & $\begin{array}{l}\text { Feldspathic, } \\
\text { IPS Empress } \\
\text { e-Max }\end{array}$ & 150 & Metallic & $\begin{array}{l}\text { Ti:sapphire, } \\
\text { Er:YAG, } \\
\text { Nd:YAG }\end{array}$ & $\begin{array}{c}\text { Ti:sapphire/Er:YAG/Nd:YAG, } \\
\text { sandblasting/HF, light cure } \\
\text { adhesive }\end{array}$ & $\begin{array}{l}\text { Feldspathic similar to IPS } \\
\text { Empress e-Max } \\
\text { Ti:sapphire >sandblasting }>\text { HF } \\
\text { ER:YAG similar to Nd:YAG, } \\
\quad \text { lower values }\end{array}$ & $\begin{array}{l}\text { Thermocycling, } \\
\text { SEM } \\
\text { SEM showed } \\
\text { regular surfaces } \\
\text { obtained for } \\
\text { Ti:Sapphire }\end{array}$ \\
\hline [15] & Feldspathic & 80 & Metallic & $\begin{array}{l}\text { Fractional } \mathrm{CO}_{2} \\
\text { laser }\end{array}$ & $\begin{array}{c}\text { Fractional } \mathrm{CO}_{2} \text { laser for } 10 \\
\mathrm{~s} 10 \mathrm{~mJ}, 200 \mathrm{~Hz} \text { and powers } \\
\text { of } 10 \mathrm{~W} / 15 \mathrm{~W} / 20 \mathrm{~W} / 9.6 \% \\
\mathrm{HF} 2 \text { min.silane for all, } \\
\text { deglazing for half of } \\
\text { specimens }\end{array}$ & $\begin{array}{l}\text { Deglazing sgn increased } \\
\text { SBS of laser treated } \\
\text { porcelain surfaces, but no } \\
\text { sgn effect on SBS when } \\
\text { using HF. SBSs } 10 \mathrm{~W} \text { and } \\
15 \mathrm{~W} \text { laser groups sgn } \\
\text { higher than HF group }\end{array}$ & \\
\hline [16] & Feldspathic & 48 & Metallic & Nd:YAG & $\begin{array}{c}\text { Control/HF/grooved/0.75 } \\
\text { W laser/1.05 W/1.45 W }\end{array}$ & $\begin{array}{l}\text { Nd:YAG } 1.05 \mathrm{~W} \text { and HF } \\
\text { could increase the bonding } \\
\text { SBS and TBS, SBS and } \\
\text { TBS-correlated }\end{array}$ & \\
\hline [17] & Feldspathic & 60 & Metallic & $\begin{array}{c}\text { Er:YAG } \\
\text { Er:CrYSGG }\end{array}$ & $\begin{array}{c}\text { 9\% HF } 2 \text { min } / 9 \% \text { HF } 2 \text { min } \\
\text { + Er:CrYSGG laser } / 9 \% \text { HF } \\
2 \text { min + Er:YAG } \\
\text { laser/Er:CrYSGG } \\
\text { laser/Er:YAG laser. } \\
\text { Transbond XT primer + } \\
\text { adhesive for all }\end{array}$ & $\begin{array}{l}\text { Sgn difference in SBS } \\
\text { between the first three } \\
\text { groups and the two laser } \\
\text { groups. Er:YAG laser 3-W } \\
\text { power, } 10-\mathrm{Hz} \text { frequency for } \\
10 \mathrm{~s} \text { is not an alternative to } \\
\text { HF. Er:CrYSGG laser, met } \\
\text { minimal criteria } 6-8 \mathrm{MPa}\end{array}$ & $\begin{array}{l}\text { Thermocycling } \\
5000 \text { cycles } \\
\text { SEM }\end{array}$ \\
\hline
\end{tabular}


Table 2. Cont.

\begin{tabular}{|c|c|c|c|c|c|c|c|}
\hline No Ref. & Ceramic Type & Samples No & Bracket Type & Laser Type & Adhesion Type & Results & $\begin{array}{c}\text { Additional } \\
\text { Examination }\end{array}$ \\
\hline [18] & Feldspathic & 42 & Metallic & Er:YAG & $\begin{array}{c}\text { APA } / 9.6 \% \mathrm{HF} / \mathrm{Er}: \mathrm{YAG} \\
\text { irradiation }(2 \mathrm{~W}, 10 \mathrm{~Hz} \text { for } \\
10 \mathrm{~s})\end{array}$ & Er:Yag = HF > APA & \\
\hline [19] & Feldspathic & 150 & Metallic & $\begin{array}{l}\text { Er:YAG short } \\
\text { pulse and } \\
\text { super short } \\
\text { pulse }\end{array}$ & $\begin{array}{l}5 \text { groups RelyX U 200, } \\
5 \text { groups Transbond XT. } \\
\text { APA/Er:YAG short pulse } \\
\text { SP/Er:YAG laser super } \\
\text { short pulse } \\
\text { SSP/sandblasted+SP/ } \\
\text { sandblasted+SSP }\end{array}$ & $\begin{array}{l}\text { Er:YAG laser did not allow } \\
\text { the elimination of HF. } \\
\text { RelyX U } 200 \text { an alternative } \\
\text { to Transbond XT on } \\
\text { sandblasted porcelain. } \\
\text { Highest SBS sandblasting } \\
\text { and Transbond XT. }\end{array}$ & \\
\hline [20] & Feldspathic & 100 & Metallic & Er:YAG lasers & $\begin{array}{l}\text { Deglazing, silane for all, } \\
\text { 9.6\% HF/Er:YAG lasers of } \\
\text { 1.6, 2, and } 3.2 \mathrm{~W}\end{array}$ & $\begin{array}{l}\text { Mean SBS in the laser } \\
\text { group with power of } 1.6 \mathrm{~W} \\
>\mathrm{HF}, 2-\mathrm{W} \text { power, } 3.2-\mathrm{W} \\
\text { power groups, but not sgn }\end{array}$ & \\
\hline$[21]$ & Feldspathic & 80 & Metallic & $\begin{array}{l}\text { Ti:sapphire } \\
\text { femtosecond, } \\
\text { Nd:YAG laser }\end{array}$ & $\begin{array}{c}\text { Ti:sapphire } \\
\text { femtosecond/APA/ } 9.6 \% \\
\text { HF/Nd:YAG laser, silane } \\
\text { for all }\end{array}$ & $\begin{array}{l}\text { Group Nd:YAGsgn lower } \\
\text { than the other groups, no } \\
\text { sgn differences between the } \\
\text { other groups. }\end{array}$ & $\begin{array}{l}\text { Thermocycling } \\
500 \text { cycles }\end{array}$ \\
\hline [22] & Feldspathic & 72 & Metallic & Nd:YAG & $\begin{array}{c}9.6 \% \mathrm{HF} 4 \mathrm{~min} / 0.75-, 1- \\
1.25-, 1.5-, \text { and } 2-\mathrm{W} \\
\text { Nd:YAG for } 10 \mathrm{~s} .\end{array}$ & $\begin{array}{c}\text { No sgn differences between } \\
\text { HF lasers with power of } 1.5 \\
\text { or } 2 \text { W; no sgn difference } \\
\text { between all test groups in } \\
\text { ARI scores }\end{array}$ & $\begin{array}{l}\text { Thermocycling } \\
500 \text { cycles }\end{array}$ \\
\hline [23] & Feldspathic & 100 & Metallic & Nd:YAGEr:YAG & $\begin{array}{l}\text { Diamond bur/9.6\% HF } 4 \\
\text { min/0.8-W Nd:YAG/2-W } \\
\text { Er:YAG/3-W Er:YAG laser } \\
\text { for } 10 \mathrm{~s}\end{array}$ & $\begin{array}{l}\text { SBS in groups HF and } \\
0.8-W \text { Nd:YAGsgn higher }\end{array}$ & \\
\hline
\end{tabular}

\section{Discussion}

As dental ceramics are rigid, brittle and crack sensitive, but highly aesthetic and versatile, they are continuously evolving. Because of the improvement in strength of more recent, machined ceramics, dentists can use them not only for veneers, full or partial crowns, but also for implant abutments, bridgework and orthodontic brackets [24]. In 2015 Gracis et al. published a classification of dental ceramics dividing them into two main categories-glass matrix ceramic and polycrystalline ceramics [25]. A short classification of dental ceramics and their clinical indications is shown in Table 3.

Table 3. Types or ceramics and their clinical indications.

\begin{tabular}{|c|c|c|c|}
\hline & Type of Ceramic & Clinical Indications & Etchable (Yes/No) \\
\hline \multirow{6}{*}{ Glass matrix ceramics } & Feldspathic & Veneer restoration & Y \\
\hline & Leucite-based & $\begin{array}{l}\text { Veneer restoration, partial crowns } \\
\text { and anterior full crowns }\end{array}$ & $\mathrm{Y}$ \\
\hline & Licthium disilicate & $\begin{array}{c}\text { Veneer restoration, partial crowns } \\
\text { and anterior and posterior } \\
\text { full crowns }\end{array}$ & $\mathrm{Y}$ \\
\hline & Alumina & Anterior and posterior full crowns & $\mathrm{Y}$ \\
\hline & Alumina and magnesium spinel & Anterior full crowns & $\mathrm{Y}$ \\
\hline & Alumina and zirconia & Anterior and posterior full crowns & $\mathrm{Y}$ \\
\hline \multirow{3}{*}{$\begin{array}{l}\text { Polycrystalline } \\
\text { ceramics }\end{array}$} & Alumina & $\begin{array}{l}\text { Veneer restoration, anterior and } \\
\text { posterior full crowns }\end{array}$ & $\mathrm{N}$ \\
\hline & Stabilised zirconia & $\begin{array}{l}\text { Partial crowns and anterior and } \\
\text { posterior full crowns }\end{array}$ & $\mathrm{N}$ \\
\hline & $\begin{array}{l}\text { Zirconia-toughed alumina } \\
\text { Alumina-toughened zirconia }\end{array}$ & $\begin{array}{l}\text { Partial crowns and anterior and } \\
\text { posterior full crowns }\end{array}$ & $\mathrm{N}$ \\
\hline
\end{tabular}


Glass matrix ceramics consist of metallic and silica oxides within a glassy matrix, meaning they can be attacked by acids such as acidulated phosphate fluoride (APF) or hydrofluoric acid [24]. Among the glass matrix ceramics, some types are widely used even today (feldspathic, lithium disilicate, alumina), although the manufacturers are constantly working on improvements. In order to prevent the dispersion of cracks through the glass matrix, stronger polycrystals or crystalline structures are inserted into the material [24].

Contrary to glass matrix ceramics, polycrystalline ceramics (alumina, stabilised zirconia, zirconia-toughed alumina or alumina-toughened zirconia) do not contain any glass, and as a result, they are not etchable. All the atoms are included into a regular crystalline array through which it is much more difficult for cracks to disperse, compared to glass ceramics. Polycrystalline ceramics were not available in dental practice until the late 1980s when the computer-aided manufacturing was developed [24,26].

In dental practice, ceramics can be used as all-ceramic restorations or metal-ceramic. For metal-ceramic restorations, feldspathic ceramics are used to cover a metal coping. Clinical experience suggests the veneering ceramic should be about 1-2 mm thick for adequate strength and aesthetics.

Whether a type of ceramic is etchable or not is important not only in prosthodontics but also for orthodontic treatments, as the adhesion between an orthodontic bracket and a prosthetic restoration is important for the treatment's success [24].

There are several surface conditioning techniques commonly used for bonding on zirconia restorations, such as silica coating [27] sandblasting [28,29], or laser irradiation with $\mathrm{CO}_{2}$, Nd:YAG, or Er:YAG [30-33].

$\mathrm{CO}_{2}$ lasers have a gas active part which emits at a wavelength of $10.6 \mathrm{~nm}$ which is absorbed by water and hydroxyl apatite, but also by ceramic materials and it can create micro-cavities using superficial heat, enhancing the strength between resins and ceramics. Nd:YAG lasers determine melting and random re-crystallisation, determining surface roughness and increasing the strength of resin-ceramic bond [33].

However, there is still to be established an ideal surface-treatment that will provide sufficient bond strength to minimise bracket debonding from polycrystalline ceramic restorations. In this context, the aim of our research was to create a thorough image of laser use in ceramic preparation for bonding orthodontic attachments, as it is not always possible to use hydrofluoric acid for surface preparation of the ceramic restoration already placed intra-orally.

The original articles included in this review used a similar procedure for bonding brackets to ceramics: creating a ceramic surface of either feldspathic, zirconia or IPS Empress E-max type, bonding brackets using an orthodontic adhesive, mostly Transbond $\mathrm{XT}$ as the golden standard and debonding the bracket using an Instron machine that also measures shear bond strength. In some studies, thermocycling from 500 to 5000 cycles was used to create an environment that is similar to the oral cavity, as thermocycling influences adhesion. Some studies also searched the debonded ceramic samples under a scanning electron-microscope in order to find surface irregularities or cracks.

\subsection{The Effect of Laser on Non-Feldspathic Ceramic}

Only few articles focus on more recent types of ceramics, as most are developed on feldspathic porcelain. Two articles, in vitro research done by the same team lead by GarcíaSanz, focus on zirconia ceramics [12,13]. Both studies used Ti: sapphire femtosecond laser for surface preparation. In [12], 180 samples were bonded with metallic brackets, testing mainly the intensity of the femtosecond laser; the conclusion reached was that the ideal setting is $200 \mathrm{~mW}$. In the other study published by Garcia-Sanz et al., the authors focused on comparing femtosecond laser surface preparation to other types of roughening, such as air particle abrasion, silica coating and silane, and a combination of air particle abrasion and femtosecond laser. The ceramic bracket groups had higher shear bond strength values in all groups and femtosecond laser proved to be beneficial either alone or in combination with air particle abrasion for both type of brackets [13]. 
An article published in 2015 [14] compared feldspathic ceramics to IPS Empress E-max when using several types of lasers for surface preparation. The two types of ceramics showed similar shear bond strength values in all groups. Ti:sapphire laser showed higher SBS than sandblasting, and even higher than hydrofluoric acid. The ER:YAG and Nd:YAG laser had similar, lower results.

\subsection{The Effect of Laser on Feldspathic Ceramic}

Feldspathic ceramic is most commonly included in studies, as it is most often used in prosthodontics [15-23]. Only one research, published by Ahrari in 2013 [15], focuses on fractional $\mathrm{CO}_{2}$ laser use by testing different intensities of $10 \mathrm{~W}, 15 \mathrm{~W}, 20 \mathrm{~W}$ and comparing them to hydrofluoric acid. The results obtained showed that the shear bond strength obtained by using 10 and $15 \mathrm{~W}$ laser was significantly higher than the acid group; deglazing, meaning the removal of the smooth exterior layer of ceramics, helped in laser-treated ceramic surfaces. Removing the glaze layer of the restoration is considered to generally achieve better adhesion in laser-treated ceramic surfaces, as the high amounts of energy emitted by lasers seem to be better absorbed by the opaque surfaces [33]. By thermocycling for 5000 cycles, the reliability of the study developed by Mirhashemi [17] increases, concluding that combined used of HF and laser achieved significantly higher shear bond strength than laser groups and just Er:CrYSGG laser met minimal criteria for orthodontics, when used alone. Aksakalli and his team [18] showed in 2015 that Er:Yag and hydrofluoric acid had similar results, higher than air particle abrasion, which contradicts a study published in 2013 [19], that shows Er:Yag does not allow us to eliminate hydrofluoric acid application. Yassaei, in 2013 [20], shows that Er:Yag with power of 1.6 W had higher SBS than hydrofluoric acid or $3.2 \mathrm{~W}$ power. When testing feldspathic ceramics with Nd:Yag laser and Ti:Sapphire Femtosecond laser, Akpinar [21] shows that this type of laser is relatively ineffective compared to hydrofluoric acid, air particle abrasion and femtosecond laser, but Hosseini [22] contradicts these results, showing similar results of the same type of laser to hydrofluoric acid.

When comparing Nd:Yag to Er:Yag, Poosti and his team [23] show better, significantly higher results for Nd:Yag.

\section{Conclusions}

There is little difference shown by current studies between ceramic types, however newer, machined ceramics, such as zirconia and E-max are least researched in terms of orthodontic bonding.

Femtosecond laser is a good alternative to classical surface preparation by sandblasting or acid application. Nd:Yag laser is more suitable for surface preparation of ceramics than different types of Er:Yag lasers. Different power may achieve different results, but the golden standard for lasers use has not been found. Laser usage does not provide the same expected results as hydrofluoric acid. Some similar studies have opposing results. Thermocycling is not used in many studies and it may influence the results by greatly influencing adhesion. Further research is needed on newer types of ceramic and a laser use protocol has to be established in order to facilitate laser usage for surface preparation of the ceramics.

Author Contributions: Conceptualisation, A.L. and A.K.; methodology, A.L., S.S.; software, A.K.; validation, A.L., A.K., S.S.; investigation, A.L., A.K.; data curation, A.K.; writing-original draft preparation, A.L.; writing - review and editing, A.K., S.S.; supervision, S.S.; project administration, A.K. All authors have read and agreed to the published version of the manuscript.

Funding: This research received no external funding.

Institutional Review Board Statement: Not applicable.

Informed Consent Statement: Not applicable.

Data Availability Statement: Not applicable. 
Conflicts of Interest: The authors declare no conflict of interest.

\section{References}

1. Maiman, T.H. Stimulated optical radiation in ruby lasers. Nature 1960, 187, 493. [CrossRef]

2. Goldman, L.; Goldman, B.; Van-Lieu, N. Current laser dentistry. Lasers Surg. Med. 1987, 6, 559-562. [CrossRef] [PubMed]

3. RP Photonics Encyclopedia. Available online: https://www.rp-photonics.com/encyclopedia.htm (accessed on 22 January 2021).

4. Miserendino, L.J.; Pick, R.M. Current applications of lasers in dentistry. In Lasers in Dentistry; Quintessence Publishing Co, Inc: Singapore, 1995; pp. 126-128.

5. Verma, S.; Chaudhari, P.; Maheshwari, S.; Singh, R. Laser in dentistry: An innovative tool in modern dental practice. Natl. J. Maxillofac. Surg. 2012, 3, 124-132. [CrossRef] [PubMed]

6. Harashima, T.; Kinoshita, J.I.; Kimura, Y.; Brugnera, A., Jr.; Zanin, F.; Pecora, J.D.; Matsumoto, K. Morphological comparativestudy on ablation of dental hard tissue at cavity preparation by Er: YAG and Er, CR: YSGG lasers. Photomed. Laser Ther. 2005, 23, 52-55. [CrossRef] [PubMed]

7. Ishikawa, I.; Aoki, A.; Takasaki, A.A. Clinical application of erbium: YAG Laser in periodontology. J. Int. Acad. Periodontol. 2008, $10,22-30$.

8. Hilgers, J.J.; Tracey, S.G. Clinical uses of diode lasers in orthodontics. J. Clin. Orthod. 2004, 38, $266-273$.

9. Moulton, P.F. Spectroscopic and laser characteristics of Ti: $\mathrm{Al}_{2} \mathrm{O}_{3}$. J. Opt. Soc. Am. B 1986, 3, 125-133. [CrossRef]

10. Nalcaci, R.; Cokakoglu, S. Lasers in orthodontics. Eur. J. Dent. 2013, 7, 1-10. [CrossRef] [PubMed]

11. Wassell, R.; Nohl, F.; Steele, J.; Walls, A. Extra-Coronal Restorations: Concepts and Clinical Application, 2nd ed.; Springer: Cham, UK, 2019; pp. 179-192.

12. García-Sanz, V.; Paredes-Gallardo, V.; Bellot-Arcís, C.; Martínez-León, L.; Torres-Mendieta, R.; Montero, J.; Albaladejo, A. Femtosecond laser settings for optimal bracket bonding to zirconia. Lasers Med. Sci. 2019, 34, 297-304. [CrossRef]

13. García-Sanz, V.; Paredes-Gallardo, V.; Bellot-Arcís, C.; Mendoza-Yero, O.; Doñate-Buendía, C.; Montero, J.; Albaladejo, A. Effects of femtosecond laser and other surface treatments on the bond strength of metallic and ceramic orthodontic brackets to zirconia. PLOS ONE 2017, 12, e0186796.

14. Erdur, E.A.; Basciftci, F.A. Effect of Ti:sapphire laser on shear bond strength of orthodontic brackets to ceramic surfaces. Lasers Surg. Med. 2015, 47, 512-519. [CrossRef]

15. Ahrari, F.; Heravi, F.; Hosseini, M. $\mathrm{CO}_{2}$ laser conditioning of porcelain surfaces for bonding metal orthodontic brackets. Lasers Med. Sci. 2013, 28, 1091-1097. [CrossRef]

16. Tai, Y.; Zhu, X.; Tang, G.; Wang, G.; Mao, Z. Influence of different surface treatments in bond strength of brackets to porcelain. J. Jilin Univ. Med. Ed. 2015, 41, 1207-1210.

17. Mirhashemi, A.; Chiniforush, N.; Jadidi, H.; Sharifi, N. Comparative study of the effect of Er:YAG and Er:Cr;YSGG lasers on porcelain: Etching for the bonding of orthodontic brackets. Lasers Med. Sci. 2018, 33, 1997-2005. [CrossRef] [PubMed]

18. Aksakalli, S.; Ileri, Z.; Yavuz, T.; Malkoc, M.A.; Ozturk, N. Porcelain laminate veneer conditioning for orthodontic bonding: SEM-EDX analysis. Lasers Med. Sci. 2015, 30, 1829-1834. [CrossRef] [PubMed]

19. Topcuoglu, T.; Oksayan, R.; Topcuoglu, S.; Coskun, M.E.; Isman, N.E. Effect of Er:YAG laser pulse duration on shear bond strength of metal brackets bonded to a porcelain surface. Photomed. Laser Surg. 2013, 31, 240-246. [CrossRef] [PubMed]

20. Yassaei, S.; Moradi, F.; Aghili, H.; Kamran, M.H. Shear bond strength of orthodontic brackets bonded to porcelain following etching with Er:YAG laser versus hydrofluoric acid. Orthod. Chic. 2013, 14, e82-e87. [CrossRef] [PubMed]

21. Akpinar, Y.Z.; Irgin, C.; Yavuz, T.; Aslan, M.A.; Kilic, H.S.; Usumez, A. Effect of femtosecond laser treatment on the shear bond strength of a metal bracket to prepared porcelain surface. Photomed. Laser Surg. 2015, 33, 206-212. [CrossRef]

22. Hosseini, M.H.; Sobouti, F.; Etemadi, A.; Chiniforush, N.; Shariati, M. Shear bond strength of metal brackets to feldspathic porcelain treated by Nd:YAG laser and hydrofluoric acid. Lasers Med. Sci. 2015, 30, 837-841. [CrossRef] [PubMed]

23. Poosti, M.; Jahanbin, A.; Mahdavi, P.; Mehrnoush, S. Porcelain conditioning with Nd:YAG and Er:YAG laser for bracket bonding in orthodontics. Lasers Med. Sci. 2012, 27, 321-324. [CrossRef] [PubMed]

24. Gracis, S.; Thompson, V.P.; Ferencz, J.L.; Silva, N.R.; Bonfante, E.A. A new classification system for all-ceramic and ceramic-like restorative materials. Int. J. Prosthodont. 2015, 28, 227-235. [CrossRef] [PubMed]

25. Chavali, R.; Nejat, A.H.; Lawson, N.C. Machinability of CAD-CAM materials. J.Prosthet. Dent. 2017, 118, 194-199. [CrossRef] [PubMed]

26. Spohr, A.M.; Borges, G.A.; Júnior, L.H.; Mota, E.G.; Oshima, H.M. Surface modification of In-Ceram Zirconia ceramic by Nd:YAG laser, Rocatec system, or aluminum oxide sandblasting and its bond strength to a resin cement. Photomed. Laser Surg. 2019, 26, 203-208. [CrossRef] [PubMed]

27. Gomes, A.L.; Oyagüe, R.C.; Lynch, C.D.; Montero, J.; Albaladejo, A. Influence of sandblasting granulometry and resin cement composition on microtensile bond strength to zirconia ceramic for dental prosthetic frameworks. J. Dent. 2013, 41, 31-41. [CrossRef]

28. Mosharraf, R.; Rismanchian, M.; Savabi, O.; Ashtiani, A.H. Influence of surface modification techniques on shear bond strength between different zirconia cores and veneering ceramics. J. Adv. Prosthodont. 2011, 3, 221-228. [CrossRef]

29. Cavalcanti, A.N.; Foxton, R.M.; Watson, T.F.; Oliveira, M.T.; Giannini, M.; Marchi, G.M. Bond strength of resin cements to a zirconia ceramic with different surface treatments. Oper. Dent. 2009, 34, 280-287. [CrossRef] 
30. Akin, H.; Ozkurt, Z.; Kımalı, O.; Kazazoglu, E.; Ozdemir, A. Shear bond strength of resin cement to zirconia ceramic after aluminium oxide sandblasting and various laser treatments. Photomed. Laser Surg. 2011, 29, 797-802. [CrossRef]

31. Paranhos, M.P.; Burnett, L.H., Jr.; Magne, P. Effect of Nd:YAG laser and $\mathrm{CO}_{2}$ laser treatment on the resin bond strength to zirconia ceramic. Quintessence Int. 2011, 42, 79-89.

32. Gomes, A.L.; Ramos, J.C.; Santos-del Riego, S.; Montero, J.; Albaladejo, A. Thermocycling effect on microshear bond strength to zirconia ceramic using Er:YAG and tribochemical silica coating as surface conditioning. Lasers Med. Sci. 2015, 30, 787-795. [CrossRef]

33. Mirhashemi, A.; Sharifi, N.; Moharrami, M.; Chiniforush, N. Evaluation of Different Types of Lasers in Surface Conditioning of Porcelains: A Review Article. Lasers Med. Sci. 2017, 8, 101-111. [CrossRef] 